\title{
DEBT CRISIS AND INFLATION*
}

\author{
Maria Cristina T. Terra**
}

\begin{abstract}
This paper develops and tests a model that predicts a negative link between the degree of openness of an economy and its equilibrium inflation rate. The effect arises in an economy going through a debt crisis, and in which inflation tax constitutes an important source of the government's revenue. The predictions of the analysis are compared to those in Romer (1993), which uses a Barro-Gordon type model to argue that openness puts a check on a government's incentive to engage in unanticipated inflation, because of induced exchange rate depreciation. Romer's tests are reevaluated, and it is shown that the degree of openness is only a significant determinant of inflation among highly indebted countries, during the debt crisis period. The empirical results indicate that the model of openness and inflation presented here explains the data better than Romer.
\end{abstract}

\section{Resumo}

Neste artigo é desenvolvido e testado um modelo que prevê uma relação negativa entre o grau de abertura de uma economia e sua taxa de inflação de equilíbrio. O efeito surge em uma economia passando por uma crise de dívida externa, e na qual o imposto inflacionário é uma importante fonte de receita do governo. As previsões do modelo são comparadas às de Romer (1993), onde um modelo do tipo Barro-Gordon é usado para mostrar que o grau de abertura da economia diminui o incentivo a inflacionar, devido à depreciação cambial que seria dessa forma gerada. Os testes empíricos apresentados em Romer (1993) são reavaliados, e este artigo mostra que o grau de abertura é uma variável significativa na determinação da taxa de inflação apenas entre países muito endividados, durante o período de crise da dívida externa. Os resultados empíricos indicam que o modelo que relaciona abertura à inflação apresentado neste artigo oferecern uma melhor explicação para o comportamento dos dados do que o modelo de Romer (1993).

* I thank Kenneth Rogoff, Peter Kenen, Laurence Ball, Afonso Bevilaqua, participants in the Department of Economics seminar at PUC-Rio and in the Modeling Inflation session at the Econometric Society 7 th World Congress for very useful comments and suggestions. All remaining errors are my own. I am grateful to CNPq, Brazil, for financial assistance.

** Departamento de Economia, PUC-Rio.

\begin{tabular}{llllll}
\hline R. de Econometria & Rio de Janeiro & v. $17, \mathrm{n}^{\mathrm{O}}$ & 2 2, & pp. 21-48 & Novembro 1997 \\
\hline
\end{tabular} 
Key words: Openness, inflation, debt crisis.

JEL Code: E31 e F34.

\section{Introduction.}

A new view on how the degree of openness may affect the equilibrium inflation rate is presented in this paper, and an empirical study is performed to test its validity. The argument for a negative link between inflation and openness relates to the literature that recognizes the dual resource transfer necessary for a country's repayment of a large public external debt. ${ }^{1} \mathrm{On}$ the one hand, trade surpluses have to be generated to make the debt repayment, which is characterized as the external transfer. On the other hand, due to the fact that in many developing countries the foreign debt is to a large extent a public liability, resources have to be drawn from the private to the public sector for debt repayment, characterizing the internal transfer. The point this paper illustrates is that in less open economies the external transfer is harder to be implemented, making it necessary to have a more devalued exchange rate. The devaluation of the exchange rate, in turn, tightens the internal constraint: more resources have to be transferred from the private to the public sector. When inflation tax is the major mechanism for this transfer, a higher inflation rate will result.

A different explanation for a negative link between inflation and openness is offered by the literature on the effect of lack of precommitment in monetary policy on the equilibrium inflation rate in economies where monetary policy can affect real output. The main theme of that literature is that the government has an incentive to inflate unexpectedly in order to increase output. ${ }^{2}$ Rogoff (1985) shows

\footnotetext{
ISee Cohen (1987), Rodrik (1990), and Bevilaqua (1993), among others.

${ }^{2}$ Kydland and Prescott (1977) and Barro and Gordon (1983) are classic references in this literature.
} 
that, in an open economy, output increases generated by unanticipated monetary expansion causes real exchange rate depreciation, and the depreciation lowers the benefits of the expansion. This leads to the prediction that more open economies would tend to have lower inflation rates in the absence of precommitment in monetary policy. Romer (1993) tests empirically this prediction.

The empirical findings of this paper are confronted with those in Romer (1993), which shows a regression of the degree of openness on inflation for a large sample of countries yielding a negative and significant link between the two variables. This paper shows that when the openness and inflation relation is allowed to differ among groups of countries separated accordingly to indebtedness level, it disappears in all groups of countries, except for the group of highly indebted countries. Moreover, when the time frame studied is split between the pre-debt crisis and debt crisis periods, the relation is notably stronger during the latter. Terra (1998) presents further empirical evidence on indebtedness driving the openness and inflation negative relation.

The paper is organized as follows. Section 2 studies the link between inflation and openness, contrasting the new proposed view with the one in the precommitment literature. Section 3 presents the empirical findings, and section 4 concludes.

\section{Openness and Inflation.}

This section will first outline the argument for a negative link between inflation and openness derived from "precommitment models", followed by a brief description of the main results of the empirical results from Romer (1993), which tests empirically the validity of the prediction.

An alternative model will then be constructed which also predicts a negative link between inflation and openness. The effect arises in an economy going through a debt crisis, and where inflation tax 
constitutes an important source of the government's revenue. As it will become clear, the two approaches offer completely different reasons for a negative link between inflation and openness, therefore yielding different policy implications. In section 3 , an empirical study will show that the alternative model presented here is the one that better explains the behavior of the data.

\subsection{Precommitment in monetary policy and inflation.}

The main assumption in "precommitment models" is that the economy has nominal stickiness in prices or wages, so that unanticipated monetary shocks have both nominal and real effects in the economy. In that case, departures of output $(y)$ from its natural rate $\left(y^{*}\right)$ can be represented as a linear function of the difference between actual inflation rate $(\pi)$ and the expected one $\left(\pi^{e}\right)$,

$$
y=y^{*}+\delta\left(\pi-\pi^{e}\right)
$$

where $\delta>0$.

It is assumed that the policy maker's objective function depends positively on changes of output above its natural rate, and negatively on the inflation rate. The objective function may be written as:

$$
W=-\frac{1}{2} \pi^{2}+\phi y
$$

for simplicity, for $\phi>0$.

The policy maker chooses the rate of money growth so as to maximize his objective function, taking as given the rate of inflation expected by the private agents. But when private agents form their inflation rate expectation, they take into account the problem the policy maker will be facing, and form their expectations accordingly. The resulting equilibrium will be a (properly expected) positive inflation rate, with no real effects. 
Rogoff (1985) includes one more piece in this framework: the effect of trade with the rest of the world is considered. With the same basic framework as before, the policy maker will be tempted to set the rate of money growth above the one consistent with zero inflation in an attempt to increase output above its natural rate. Two effects come into play in an open economy. First, the increase in domestic output relative to output abroad will reduce its relative price, provided they are not perfect substitutes. This will lower the benefit of the output expansion, and the larger the fraction of goods imported, the lower will be the benefit of the monetary expansion. This effect will make $\phi$ be smaller in more open economies. Second, as the increase in the domestic output is driven by the change in domestic prices, and real depreciation means that foreign prices increase more rapidly than domestic prices, then a given domestic output increase will be associated with a higher inflation the more open the economy is. That is, the output/inflation trade off changes with the degree of openness of the economy: increased openness reduces $\delta$ is equation (1). These two effects combined will lower the benefit of an unanticipated monetary expansion.

A result that can be drawn from this theory is that in an economy with nominal stickiness and no precommitment to monetary policy, the equilibrium inflation rate will be lower the more open the economy is. Romer (1993) tests this prediction in the data, regressing inflation rates on the degree of openness for as large a sample of countries as possible. He uses the average inflation rate and the degree of openness ${ }^{3}$ for a sample of 114 countries since 1973. Romer observes that, because "the Bretton Woods system limited countries' ability to pursue independent monetary policies, the post-1973 regime appears to provide a better setting to test the theory". His basic regression yields a promising result: the coefficient of the degree

${ }^{3}$ The inflation rate is measured in logs, and the measure for the degree of openness used is the ratio between imports and GDP. 
of openness is negative (-1.006) and significant, with a t-statistic of -3.8. For robustness check, he includes in the regression real income per capita, dummies for alternative sources of data, regional dummies, and divides the countries in sub-samples. ${ }^{4}$ The link between inflation and openness is always negative, but the null hypotheses that they are equal to zero cannot be rejected in most sub-samples.

However, as section 3 will show, the negative link between inflation and openness found in Romer (1993) over a large sample of countries and a broad time frame is actually caused by a sub-sample of the countries over a limited time period. More specifically, it is caused by the severely indebted countries over the debt crisis period. Before this empirical finding is presented, an alternative explanation for a negative link between openness and inflation will be developed.

\subsection{Debt crisis and inflation.}

This section presents a model open economy in which a negative link between inflation and openness appears when it is going through a debt crisis. In the model, changes in nominal variables have no real effects, hence monetary policy does not affect the real exchange rate. Inflation arises because the government has to resort to money creation to service its foreign debt.

The effect arises in a highly indebted small open economy in which seignorage constitutes an important part of the government's total revenue. The less open the economy, the greater is the effort to produce the necessary trade surplus that equilibrates the balance of payments, which means that less open economies will need a more devalued exchange rate. The exchange rate, on the other hand, affects the government's budget deficit, as it affects the local currency

\footnotetext{
${ }^{4}$ The sub-samples are: countries with average inflation higher than $30 \%$ excluded, countries without independent monetary policy excluded, a sample only with countries with good quality data, and regional sub-samples - OECD (as a region), Africa, South America, Central America and Asia.
} 
value of the debt service. Consequently, it will also affect the amount of inflation tax the government needs to collect and less open highly indebted economies will have higher inflation rates. The negative relation between openness and inflation is derived from a model economy where changes in nominal variables have no real effects, hence monetary policy does not affect the real exchange rate.

First, the equilibrium inflation rate will be derived as a function of the ratio between the real exchange rate and real money balances. Then, the ratio between real exchange rate and real money balances will be shown to depend negatively on the degree of openness of the economy in an indebted country going through a debt crisis.

There are $N$ goods in this economy divided into two sectors: goods $X_{1}, \cdots, X_{T}$ are in the tradable goods' sector, and goods $X_{T+1}, \cdots, X_{N}$ are in the non-tradable goods' sector. The country is small in the international goods market, and the domestic price of each tradable good is $p_{t \tau}=E_{\tau} p_{t \tau}^{*}$, for $0 \leq t \leq T$, where $E_{\tau}$ is the nominal exchange rate at period $\tau$, and $p_{t \tau}^{*}$ is the (exogenous) international price of the tradable good $t$, taken as being equal to 1 for every good.

Every firm in the economy faces perfect competition, and, for simplicity, every firm has the same production function. Let $e=$ $p_{t} / p_{n}$ be the real exchange rate, ${ }^{5}$ where $p_{t}$ and $p_{n}$ are the prices of the tradable and non-tradable goods, respectively. Assuming full employment of the fixed factor endowments, the producer of each good chooses optimally its production point, resulting in the following supply functions for a representative tradable and non-tradable good, respectively: ${ }^{6}$

$$
\begin{aligned}
& X_{t}^{s}=X_{t}^{s}(e) \\
& X_{n}^{s}=X_{n}^{s}(e)
\end{aligned}
$$

5 The definition of the real exchange rate summarizes incentives that guides resource allocation between the two sectors of the economy.

${ }^{6}$ Time subscripts are omitted wherever it is not confusing to do so. 
where $X_{t}^{s}$ and $X_{n}^{s}$ represent the supply of a tradable and a nontradable good; $\frac{d X_{t}^{s}(e)}{d e}>0$ and $\frac{d X_{n}^{s}(e)}{d e}<0$.

Consumers maximize utility, subject to their budget constraint. It is also assumed that their demand for goods depends positively on the amount of money they hold. Two possible ways to derive this assumption are either by a cash-in-advance constraint, ${ }^{7}$ or by placing money in the utility function. The demand for each type of good may be represented by:

$$
\begin{aligned}
& X_{t}^{d}=X_{t}^{d}(m, e) \\
& X_{n}^{d}=X_{n}^{d}(m, e)
\end{aligned}
$$

where $X_{t}^{d}$ and $X_{n}^{d}$ represent the demand for a tradable and a nontradable good, respectively, real cash balances in terms of nontradable goods ${ }^{8}$ is $m \equiv M / p_{n}, M$ being the nominal money stock, $\frac{\partial X_{t}^{d}(m, e)}{\partial e}<0$ and $\frac{\partial X_{n}^{d}(m, e)}{\partial e}>0$.

In equilibrium, the demand for a non-tradable good has to equal domestic supply. The real money balances and the real exchange rate have then to satisfy the following condition in equilibrium:

$$
X_{n}^{d}=X_{n}^{d}(m, e)
$$

Furthermore, the country's resource constraint dictates that the variation in foreign debt, to which only the government has access, must equal the sum of interest payments on previously contracted foreign debt and the trade balance:

$$
F_{\tau}-F_{\tau-1}=r F_{\tau}+F\left[X_{t}^{s}-X_{t}^{d}\right]
$$

\footnotetext{
${ }^{7}$ Appendix A derives the consumer problem using a cash-in-advance constraint.

8 The real money supply is defined in terms of the price of non-tradable goods for analytical convenience only. It will play no role in the model.
} 
where $r$ is the international interest rate, taken as being exogenous and constant over time, and $F_{\tau}$ is the amount of external debt owed by the government at period $\tau$.

It is assumed that there is an upper limit of foreign credit available for the government, i.e., $F_{\tau} \leq \bar{F}$. A debt crisis period can be represented as the government inheriting a debt equal to its upper limit, i.e., not being able to borrow more. In a debt crisis, the resource constraint becomes:

$$
r F_{\tau-1}=T\left[X_{t, \tau}^{s}-X_{t, \tau}^{d}\right]
$$

Equations (5) and (7) determine the equilibrium values of the real exchange rate and real money balances in the economy. They ensure that the domestic market is in equilibrium, and that the trade surplus generates enough foreign resources for the country to meet its external financial obligations. These resources, however, are generated by the private sector, and the external debt is a public liability. Hence, how the resources are transferred from the private to the public sector has to be specified.

The government's budget constraint is added to this framework. Government expenditures are exogenously given. The two sources of government financing are credit creation and foreign borrowing, that is, either the government brings money from abroad, or it transfers money from the private sector through the inflation tax. It yields the following budget constraint for the government:

$$
E_{\tau}\left(F_{\tau}-F_{\tau-1}\right)+M_{\tau}-M_{\tau-1}=r E_{\tau} F_{\tau-1}+G_{\tau}
$$

where $G$ is government's nominal expenditures.

The government is assumed to have two main objectives: to keep inflation as low as possible, and to maintain good reputation in the international financial markets, which translates here into always 
servicing the existing debt. For simplicity, let government expenditures equal zero. These assumptions imply that the government will always prefer to contract more debt to service old debt, and will print money only to the extent that the debt service exceeds the credit available for the country in the international financial market. Hence, during a debt crisis the government's budget constraint becomes:

$$
M_{\tau}-M_{\tau-1}=E_{\tau} r F_{\tau-1}
$$

which implies:

$$
\pi_{\tau}=\frac{e_{\tau}}{m_{\tau}} r F_{\tau-1}
$$

where $\pi_{\tau}$ is the inflation rate. As shown in Appendix A, $\frac{M_{\tau}-M_{\tau-1}}{M_{\tau-1}}=$ $\frac{p_{t \tau}-p_{t(\tau-1)}}{p_{t(\tau-1)}}=\pi_{\tau}$.

The intuition for equation (9) is as follows. To pay for its foreign debt service the government has to create money. The money creation increases the demand for all goods, as shown in equation (4). To offset this effect and restore the equilibrium real money supply, the price of non-tradable goods has to increase. The higher price of non-tradable goods, in turn, causes an appreciation of the real exchange rate. Therefore the nominal exchange rate also increases to reestablish the equilibrium real exchange rate. The rate of money creation depends on the amount the government needs to collect in local currency to meet its external financial obligations. ${ }^{9}$ The higher is the real exchange rate in relation to the real money balances necessary to maintain equilibrium in all markets, the higher will be the money creation necessary to pay for the foreign debt service, causing a higher inflation rate.

\footnotetext{
${ }^{9}$ Note that this mechanism will not be in effect if the government is itself a major exporter. In that case, the government would directly generate revenue in foreign currency, without having to transfer resources from the public in local currency, and then change it into foreign currency to pay its debt service.
} 
Figure 1

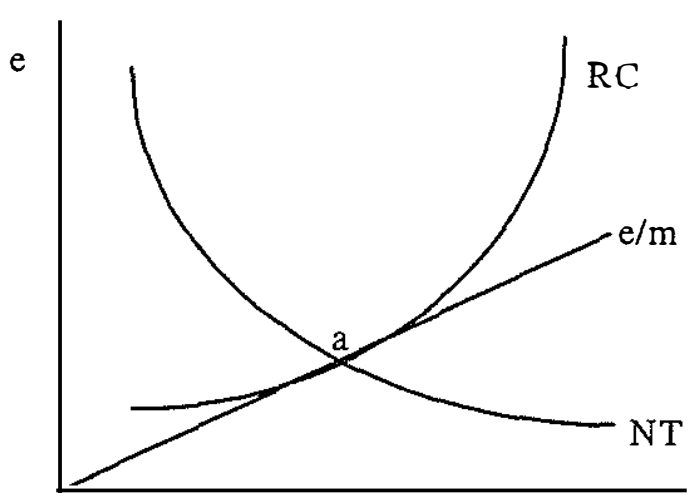

$\mathrm{m}$

Figure 1 represents the equilibrium of the economy when the foreign debt is equal to its upper limit, i.e., in a debt crisis. The schedule $N T$ represents the locus where the non-tradable goods market clears (equation (5)). The locus consistent with the country's resource constraint (equation (7)) is $R C$. The nominal exchange rate and the prices of the non-tradable goods adjust for the country's resource constraint to be satisfied and the market for non-tradable goods to clear. In equilibrium the economy is at point " $a$ " in figure 1 , and the inflation rate depends positively on the ratio $e / m$ at that point, accordingly to equation (9).

The next step is to derive the effect of the degree of openness on the equilibrium inflation rate in this model economy. Given the total number of goods, the degree of openness increases when more goods are tradable; hence the degree of openness in this model is given by the number of tradable goods. The effect of the degree of openness on the equilibrium inflation rate can be assessed by deriving the effect of changes in the number of tradable goods on the equilibrium ratio of real money supply to the real exchange rate. That is, the effect on 
the non-tradable goods market equilibrium (equation (5)) and the external resources constraint (equation (7)), or, in terms of figure 1 , the movements in the $N T$ and $R C$ schedules.

The number of tradable goods has no effect on the equilibrium condition in the non-tradable goods market. As for the external resources constraint, the more tradable goods there are, the lower needs to be the trade surplus in each of them to generate a sufficient amount of resources to service the external debt. This is translated in figure 1 as a shift of the $R C$ schedule to the right: point " $a$ " would be a point of surplus in a more open economy.

Figure 2

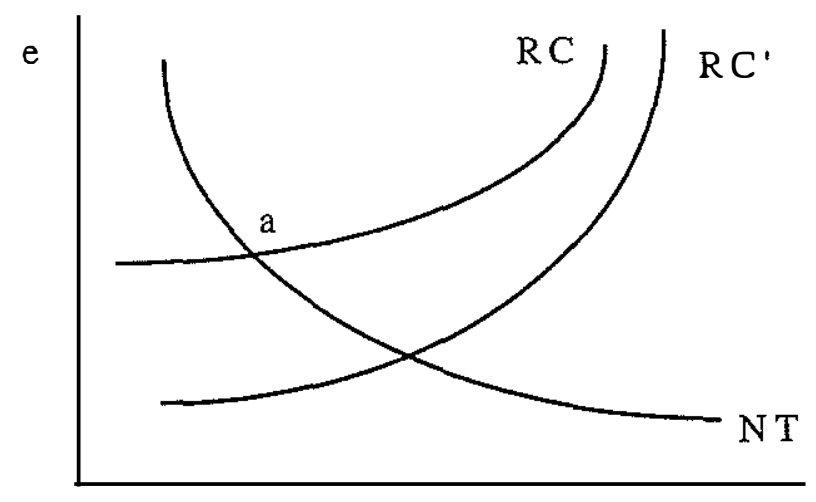

m

Figure 2 represents the effect of openness on the equilibrium of the economy. The effect of openness on the equilibrium $e / m$ ratio is negative. Therefore, according to equation (9), more open economies will have lower inflation rates, if they are producing trade surpluses.

If some countries are running trade deficits, and others trade surpluses, then the theory presented above does not predict any particular link between inflation and openness among them. During the debt crisis, however, the severely indebted countries had one feature in common: they had to have trade surpluses to pay for the foreign 
debt service. Therefore, for the severely indebted countries the theory predicts a negative link between inflation and openness over the debt crisis. The same link is not expected over different periods of time, or for different groups of countries. Empirical evidence of this result is presented in the next section.

\section{Empirical Evidence.}

An empirical investigation will now be carried on to test the validity of the alternative model presented here, which predicts a negative link between inflation and openness. This section will show that the negative link between inflation and openness found in Romer (1993) over a large sample of countries and a broad time frame is actually caused by a sub-sample of the countries over a limited time period. More specifically, it is caused by the severely indebted countries over the debt crisis period.

The national accounts data used in this paper are taken from the International Financial Statistics of the International Monetary Fund. ${ }^{10}$ To account for the theory presented in this paper, the proper measure for the degree of openness should be the ratio between the value of tradable goods and GDP, whereas for "precommitment" theory it should be the ratio between imports and total consumption. The ratio between imports and GDP is used as a proxy for openness both here and in Romer (1993). Inflation is measured as the annual change in the logarithm of GDP deflator.

The generation of sub-samples according to regional location of the countries as used by Romer (1993) does not rely on any economic difference among the countries that would imply differences in their economic behavior. It is actually a random division of the sample with respect to economic fundamentals. The level of indebtedness,

${ }^{10}$ Romer (1993) uses alternative data sources for some of his data. Refer to that paper for a through description of the data used. 
on the other hand, is a criteria that embodies an important difference among the countries regarding its economic environment.

As a first approach, the same data as Romer (1993) will be used. The sample has 114 countries, and the data is an average from 1973 to 1990. The "basic results" from that paper are reproduced, but including two sets of dummy variables in the regression of openness on inflation. ${ }^{11}$ The first set are dummy variables - denoted intercept dummies - for less indebted countries, moderately indebted countries and severely indebted countries, ${ }^{12}$ taking value 0 or 1 depending on whether the country belongs to the group or not. These variables intend to capture differences on inflation levels among the different groups of countries. The other set of dummy variables - slope dummies - is equal to the first set multiplied by the degree of openness of each country. These dummy variables capture differences in the impact of openness on inflation among the groups.

Table 1 presents the results. The first regression includes openness and the dummy variables as independent variables. The only significant coefficients in the regression are the ones for the two dummies corresponding to the severely indebted countries. They indicate that average inflation is higher among severely indebted countries, and, moreover, that a negative link between openness and inflation is statistically significant only among the countries in that group. Although the coefficients of the other dummies are not significative, it is interesting to note that the average inflation increases, and the slope of the intercept is more negative the more indebted the group

\footnotetext{
11 Terra (1998) presents further evidence of this result, but instead of using slope and intercept dummies in the openness and inflation regression, it splits the sample of countries according to indebtedness level and runs regressions for each group of countries separately.

12 The classification of indebtedness level used was that made by the World Bank in the World Bank Development Report, 1993, p.328-329. Some countries were not classified according to indebtedness level. The group "all other countries" was created for them, with no dummy variable for it. Appendix B shows the list of countries in each group.
} 
of countries. The R-Square of the regression is 0.29 . When the regression does not includes the dummy variables, as in Romer (1993), the R-square is only 0.14 .

The second regression in table 1 includes dummy variables for alternative measures of openness and inflation used when data was not available in the IFS ${ }^{13}$ and the third regression also includes real income per capita as explanatory variable for inflation. The coefficient of income is significative (t-statistic of 2.409), but has opposite sign compared to Romer (1993). The results of these regression are basically the same as the first one: openness is a significative explanatory variable for inflation only among highly indebted countries.

It is important to note that the time period over which the data is studied incorporates two distinct economic environments in the world. Developing countries were contracting their debt during the 1970's, and the debt crisis started in 1982. The data is studied for these two time periods separately, for each group of countries. The average of inflation rates and openness are taken for the whole time frame (1973-1990), for the pre-debt crisis period (1973-1981) and for the debt crisis period (1982-1990). Figures 3 and 4 present the scatterplot of openness and inflation for each group of countries separately, as well as the predicted values of the regression with the slope and intercept dummies. ${ }^{14}$

The intercept dummy is higher the more indebted the group of countries in all three regressions, being significative for the groups of moderately and severely indebted countries, indicating that more indebted countries have, in average, higher inflation rates. This result is in conformity with the explanation for the negative relation be-

\footnotetext{
${ }^{23}$ See Romer (1993).

14 This sample of countries is slightly different from the ones in Romer (1993). Countries for which data was not available in the International Financial Statistics were excluded. Some countries for which data was available, but Romer (1993) did not use, were included. The regressions using this new data set were the ones used to calculate predicted inflation in figures (3) and (4).
} 
tween inflation and openness presented above: the higher the debt, the tighter are the country's external and internal constraints, generating a higher inflation rate.

The slope dummy is negative and significative at usual significance levels only for the severely indebted countries in all three regressions, indicating that among severely indebted countries inflation and openness are negatively related. Furthermore, for that group of countries the coefficient during the debt crisis is almost two times larger than the coefficient during the pre-debt crisis period (-1.476 and -0.894 , respectively). One argument in favor of those models as supportive of the data could be that the degree of indebtedness may be correlated with the degree of precommitment in monetary policy. Countries that "over-borrowed" would also be the ones with less precommitment in monetary policy, and therefore the negative link between inflation and openness should be stronger among them. That would explain the slope dummy being significative only for the group of severely indebted countries. The "debt-crisis" argument, on the other hand, explains why the relation is so much stronger during the debt crisis. That is, inflation is in average higher in those countries, and negatively correlated to openness due to lack in precommitment in monetary policy. However, the debt crisis has clearly exacerbated the negative relation between openness and inflation.

Equation (9) in the previous section indicates that openness and foreign debt affect inflation in conjunction. On the one hand, for a given debt level, more open the economy will have a lower the equilibrium ratio between exchange rate and money supply, and therefore a lower inflation rate. On the other hand, the higher the debt, the higher the inflation rate. An interaction term was then included in the regressions - the ratio between real debt ${ }^{15}$ and openness - which will be denominated "indebtedness". Table 3 presents the results.

\footnotetext{
${ }^{15}$ Real debt was calculate as the average over the period of the ratio between debt outstanding, from the World Debt Tables, World Bank, and GDP, from the International Financial Statistics, IMF.
} 
The first band presents the regression of openness on inflation. ${ }^{16}$ The coefficient of openness is considerably higher during the debt crisis, and it is not significative in the pre-debt crisis period. The $\mathrm{R}$-Square is also higher during the debt crisis period than before the debt crisis. The second band of table 3 presents the regression of indebtedness on inflation. As expected, the coefficient of indebtedness is positive in all regressions and not significative before the debt crisis. The regression with the debt crisis data show that indebtedness is a better explanatory variable of inflation than openness: openness accounts for 5.8 percent of the cross-country variation in average inflation, whereas indebtedness accounts for 27.6 percent.

\section{Conclusion.}

This paper offers a novel explanation for a negative link between inflation and openness. The link occurs in a situation where the government inherits some foreign debt, and has to service it. If the amount of debt owed by the government has reached an upper boundary, it has to resort to money creation to service the debt. The rate of increase of money creation is a direct function of the equilibrium ratio between the real exchange rate and the real money supply. Moreover, the more open the economy is, the lower will be the exchange rate, for a given money stock, necessary to equilibrate the balance of payments, and, therefore, the lower will be the rate of increase of money. Hence, inflation will be lower in more open economies during a debt crisis.

A negative relation between inflation and openness is also a prediction of models in which lack of precommitment in monetary policy leads to excessive inflation. In those models, however, the relation should be observed over all countries with lack of precommitment in

\footnotetext{
16 The regressions presented in the first band are equivalent to the regressions in table 2 , but without the dummy variables.
} 
monetary policy, and not only among countries with large external debt as in the model presented here. Romer (1993) tests this prediction and concludes that the data are consistent with the theory, i.e., that average inflation rates are smaller in more open economies. Therefore, his findings suggest that "models in which the absence of precommitment in monetary policy leads to inefficiently high average levels of inflation are essential to understanding inflation in most of the world".

Looking at the world events through the period studied by Romer, one is struck by the turbulence in the international markets. The adverse terms of trade effect of the two oil price shocks that occurred in the 1970's led to contractionist policies in the first world, whereas less developed countries chose to continue their growth path taking advantage of the high liquidity of the international financial markets. In the early 1980's the situation changed considerably and unexpectedly. The capital inflow into the third world dropped as international interest rates rose substantially. The less developed countries, by then indebted, were facing simultaneously a sudden increase of the service on their foreign debt and lower capital inflow. They had to change their trade balances from recurrent deficits to large surpluses to meet their international financial obligations.

The relation between inflation and openness as predicted by the precommitment theory depends crucially on the effect of monetary policy on the equilibrium real exchange rate. Even if the precommitment theory actually describes a valid argument that may be relevant to policy making, it is reasonable to state that the relation between inflation and openness as explained by it may have been overwhelmed by the effects of all the action described in the previous paragraph during the time frame studied. Other considerations that enters the policy maker's objective function may have dominated the effects on the incentive to manipulate monetary policy to provoke departures from the "natural rate" of output. 
An important goal to the policy maker may be to continue as a player in the international financial market. A real exchange rate depreciation may help it to achieve that objective, as it may improve the country's trade balance. ${ }^{17}$ Countries with higher debt will suffer a higher impact from the decrease in international financial liquidity, and therefore a stronger effort will have to be made to meet its international financial duties.

Turning back to the data, from the 20 countries with average inflation greater than $20 \%$ over the period, 18 were considered severely or moderately indebted by the World Bank criteria. ${ }^{18}$

The division of the sample of countries accordingly to indebtedness level shows that the negative link between inflation and openness is negative and significant only among the severely indebted countries. Moreover, within that group of countries, the relation is strikingly stronger during the debt crisis period. The "precommitment models" do not account for this behavior of the data. The data suggest that the debt crisis triggered some phenomena responsible for the behavior observed, and it does not rely on the mechanisms suggested in the "precommitment models".

As for policy implications, Romer's theoretical explanation for the behavior of the data implied that international economic integration and cooperation would not be desirable, as it would eliminate one disincentive for governments to inflate, and therefore would lead to inefficiently higher inflation rates. The alternative explanation proposed in this paper has no such implication. Quite to the contrary: if economic integration would result in increased quantity of tradable goods in the economy, it would actually help lowering the inflation rate in an indebted economy going through a debt crisis.

\footnotetext{
${ }^{17}$ See Gylfason and Risager (1984) for a discussion and empirical evidence of how the exchange rate depreciation improves the current account.

18 World Bank Development Report, 1993, p.328-329.
} 
Debt Crisis and Inflation

Figure 3
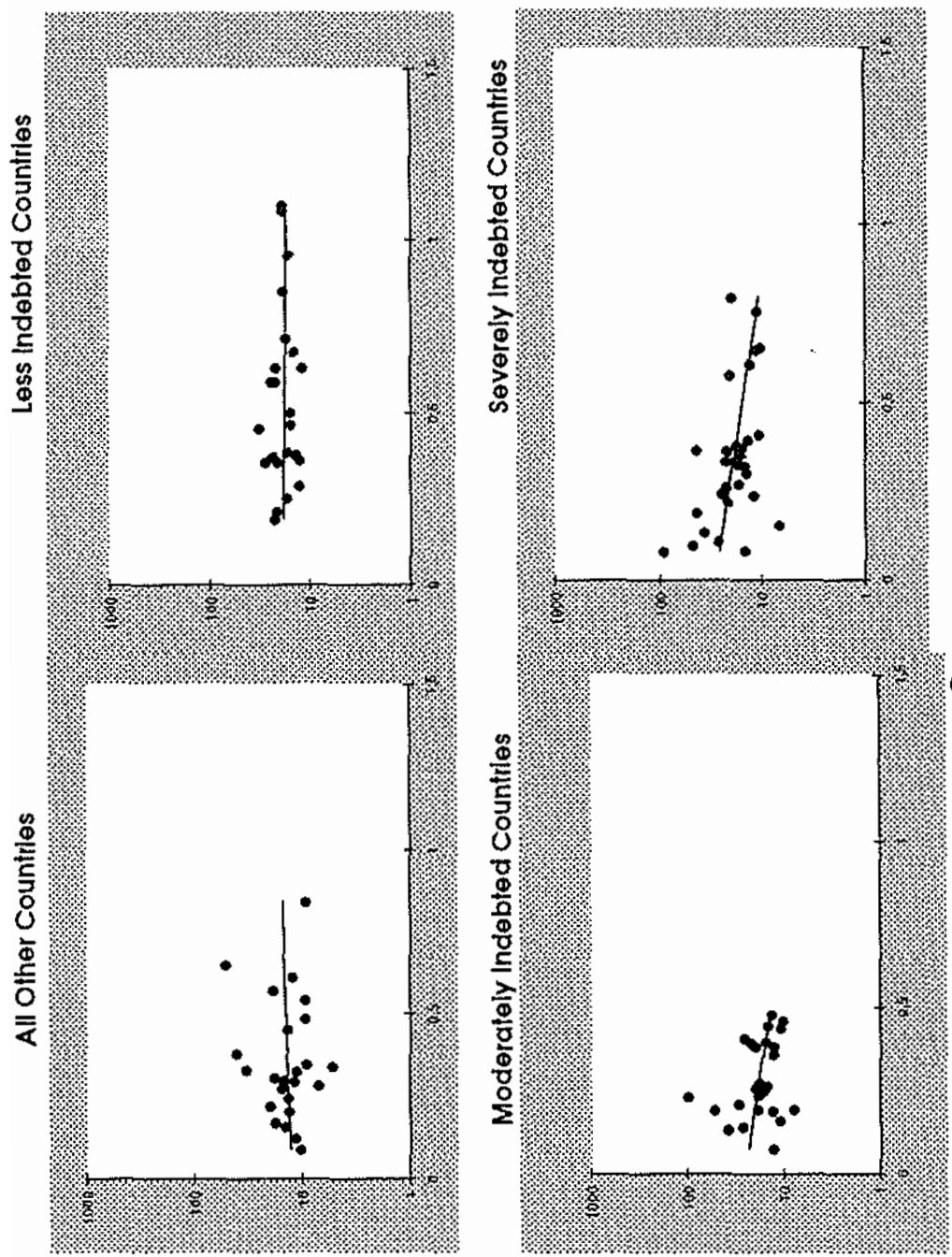

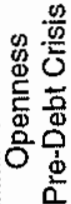

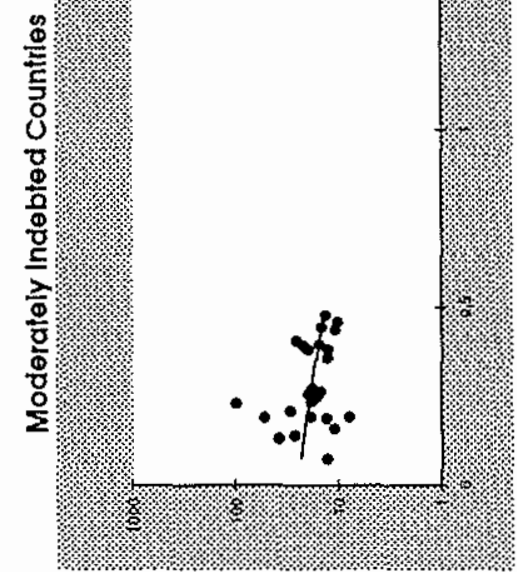

(카ess 6ol - \%) uo!ł릭 
Maria Cristina T. Terra

Figure 4
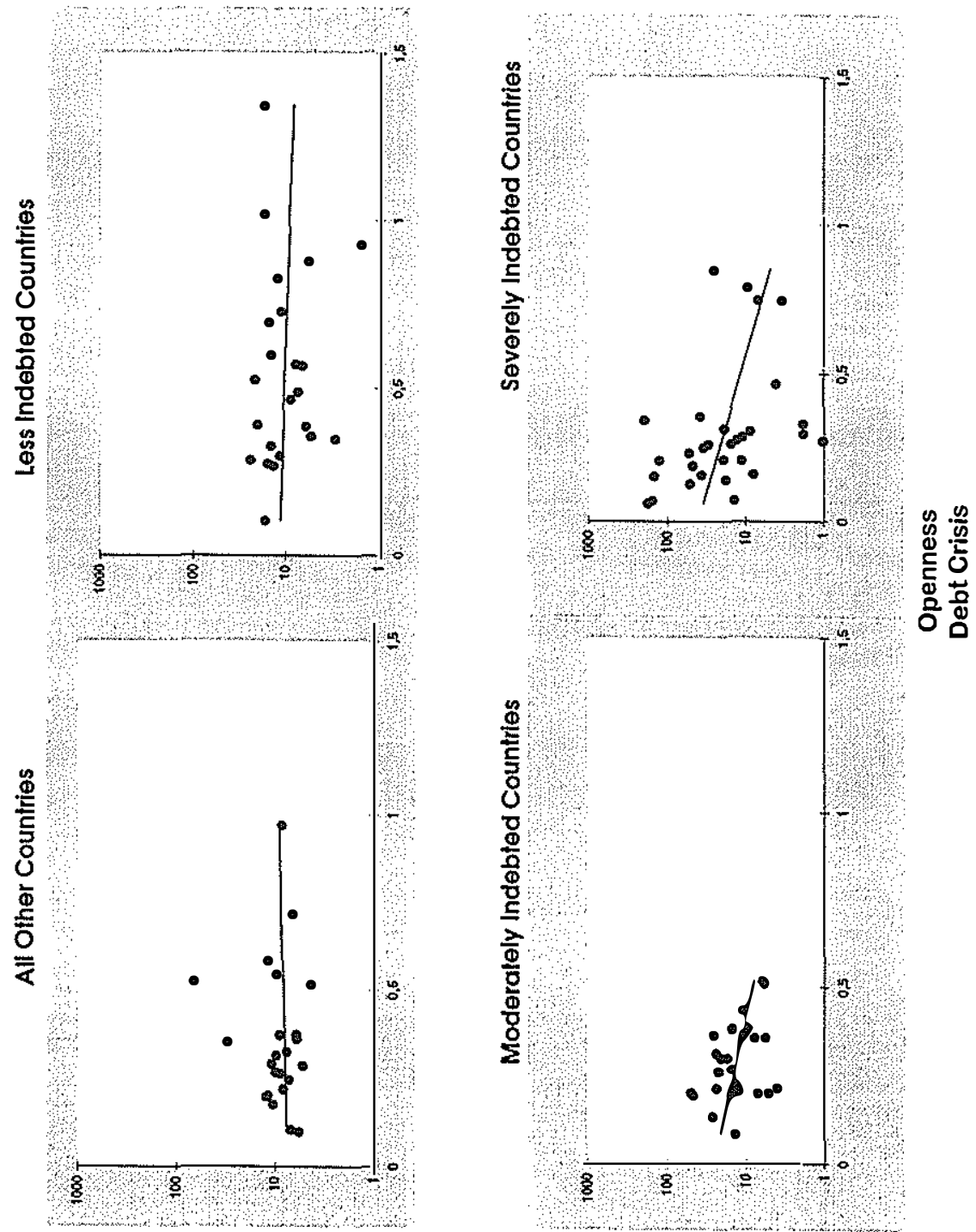

(항 6ol - \%) uo!̣ejมu 
Debt Crisis and Inflation

Table 1

\begin{tabular}{lccc}
\hline & $(1)$ & $(2)$ & $(3)$ \\
\hline Constant & -2.378 & -2.382 & -2.374 \\
& $(-12.136)$ & $(-11.638)$ & $(-12.118)$ \\
Openness & -0.237 & -0.218 & -0.335 \\
& $(-0.609)$ & $(-0.506)$ & $(-0.791)$ \\
Log real income per capita & & & 0.188 \\
& & & $(2.409)$ \\
Less indebted countries: & & & \\
Intercept dummy & 0.424 & 0.416 & 0.587 \\
& $(1.204)$ & $(1.153)$ & $(1.632)$ \\
Slope dummy & -0.414 & -0.375 & -0.295 \\
& $(-0.642)$ & $(-0.586)$ & $(-0.439)$ \\
Moderately indebted countries: & & & \\
Intercept dummy & 0.647 & 0.66 & 0.904 \\
& $(-1.869)$ & $(1.840)$ & $(2.478)$ \\
Slope dummy & -0.804 & -0.81 & -0.565 \\
& $(-0.813)$ & $(-0.801)$ & $(-0.568)$ \\
Severely indebted countries: & & & \\
Intercept dummy & 1.339 & 1.365 & 1.684 \\
& $(4.692)$ & $(4.459)$ & $(5.145)$ \\
Slope dummy & -1.912 & -1.937 & -1.825 \\
R-Square & $(-2.819)$ & $(-2.65)$ & $(-2.55)$ \\
Sample size & 0.291 & 0.293 & 0.33 \\
\hline t-statstas are in parenthes & 114 & 114 & 114 \\
\hline
\end{tabular}

t-statistics are in parentheses. Regressions (2) and (3) include dummy variables for alternative data sources (see Romer (1993)). 
Maria Cristina T. Terra

Table 2

\begin{tabular}{lccc}
\hline & $\begin{array}{c}\text { Pre-Debt } \\
\text { Crisis }\end{array}$ & $\begin{array}{c}\text { Debt } \\
\text { Crisis }\end{array}$ & $\begin{array}{c}\text { Average over } \\
73-90\end{array}$ \\
\hline Constant & -1.044 & -1.410 & -1.139 \\
& $(-8.400)$ & $(-6.739)$ & $(-7.943)$ \\
Openness & 0.172 & 0.029 & 0.125 \\
& $(0.546)$ & $(0.057)$ & $(0.353)$ \\
Less indebted countries: & & & \\
Intercept dummy & 0.137 & 0.270 & 0.194 \\
& $(0.748)$ & $(0.876)$ & $(0.920)$ \\
Slope dummy & -0.332 & -0.096 & -0.286 \\
& $(-0.856)$ & $(-0.153)$ & $(-0.654)$ \\
Moderately indebted countries: & & & \\
Intercept dummy & 0.348 & 0.811 & 0.513 \\
& $(1.807)$ & $(2.377)$ & $(2.199)$ \\
Slope dummy & -0.771 & -1.589 & -1.059 \\
& $(-1.342)$ & $(-1.547)$ & $(-1.490)$ \\
Severely indebted countries: & & & \\
Intercept dummy & 0.454 & 1.148 & 0.755 \\
& $(2.795)$ & $(4.338)$ & $(4.103)$ \\
Slope dummy & -0.894 & -1.476 & -1.260 \\
R-Square & $(-2.176)$ & $(-2.228)$ & $(-2.697)$ \\
Sample size & 0.145 & 0.322 & 0.274 \\
\hline
\end{tabular}

t-statistics are in parentheses. 
Debt Crisis and Inflation

Table 3

\begin{tabular}{lccc}
\hline & $\begin{array}{c}\text { Pre-Debt } \\
\text { Crisis }\end{array}$ & $\begin{array}{c}\text { Debt } \\
\text { Crisis }\end{array}$ & $\begin{array}{c}\text { Average over } \\
73-90\end{array}$ \\
\hline Constant & $\begin{array}{c}-1.630 \\
(-16.627)\end{array}$ & $\begin{array}{c}-1.698 \\
(-9.086)\end{array}$ & $\begin{array}{c}-1.540 \\
(-12.669)\end{array}$ \\
Openness (Imports/GDP) & -0.354 & -1.066 & -0.822 \\
& $(-1.550)$ & $(-2.486)$ & $(-2.903)$ \\
R-Square & 0.022 & 0.058 & 0.076 \\
Sample size & 105 & 103 & 105 \\
\hline Constant & -1.839 & -2.636 & -2.295 \\
& $(-17.637)$ & $(-15.155)$ & $(-19.366)$ \\
Indebtedness (Debt/Imports) & 0.194 & 0.394 & 0.459 \\
& $(1.685)$ & $(5.237)$ & $(5.869)$ \\
R-Square & 0.038 & 0.276 & 0.324 \\
Sample size & 74 & 74 & 74 \\
\hline
\end{tabular}

$\mathrm{t}$-statistics are in parentheses. 
Submetido em Julho de 1997. Revisado em Abril de 1998.

\section{References.}

Barro, Robert and Gordon, David. 1983. "Rules, discretion and reputation in a model of monetary policy." Journal of Monetary Economics XII:101-121.

Bevilaqua, Afonso. 1993. "Public External Debt and Dual Resource Transfers." Capítulo 3 da Dissertação de Doutorado, University of California, Berkeley.

Cohen, D. 1987. "Domestic and external debt constraints of LDCs." In Bryant, R. e Portes, R. eds., Global Macroeconomics. Macmillan.

Gylfason, Thorvaldur and Risager, Ole. 1984. "Does devaluation improve the current account?" European Economic Review XXV:37-40.

Kydland, Finn and Prescott, Edward. 1977. "Rules rather than discretion: the inconsistency of optimal plans." Journal of Political Economy LXXXV:473-492.

Rodrik, D. 1990. "The transfer problem in small open economies: exchange rate and fiscal policies for debt service." Ricerche Economiche XLIV:231-250.

Rogoff, Kenneth. 1985. "Can international monetary policy cooperation be counterproductive?" Journal of International Economics XVIII:199-217.

Romer, David. 1993. "Openness and inflation: theory and evidence." The Quarterly Journal of Economics CVIII:869-903.

Terra, Maria Cristina T. "Openness and inflation." The Quarterly Journal of Economics, forthcoming.

World Bank. 1993. World Bank Development Report. Oxford: Oxford University Press. 


\section{Appendix A.}

The demand function for goods and the velocity of money are derived in this appendix. All consumers have identical utility functions. The representative consumer maximize a Cobb-Douglas utility function:

$$
\sum_{\tau=v}^{\infty} \delta^{v-\tau}\left[\sum_{i=1}^{N}(1 / N) \log X_{j \tau}^{d}\right]
$$

where $\delta$ is the discount factor, $X_{j \tau}^{d}$ is the amount of good $j$ demanded at time $\tau$.

The consumer's budget constraint dictates that the amount spent on consumption plus the cash balance carried to the next period cannot exceed income plus cash balances carried in the beginning of the period. The constraint is represented by:

$$
\sum_{j=1}^{N} p_{j \tau} X_{j \tau}^{d}+M_{\tau} \leq Y_{\tau}+M_{\tau-1}
$$

where $M_{\tau}$ is the amount of money carried by the consumer in the beginning of period $\tau$, and $Y_{\tau}$ is nominal income.

In addition to the budget constraint, a cash-in-advance constraint is imposed to the consumer.

$$
\sum_{j=1}^{N} p_{j \tau} X_{j \tau}^{d} \leq M_{\tau-1}
$$

Equations (A4.a-d) represent the first order conditions for the consumer's maximization problem, given that the constraints the 
consumer faces are binding. The multipliers for the budget and cashin-advance constraints are $\lambda_{\tau}$ and $\gamma_{\tau}$, respectively.

$$
\begin{aligned}
& \frac{\delta^{v-\tau}}{N X_{j \tau}^{d}}-p_{j \tau}\left(\lambda_{\tau}+\gamma_{\tau}\right)=0 \\
& \lambda_{\tau+1}+\gamma_{\tau+1}-\gamma_{\tau}=0 \\
& \sum_{j=1}^{N} p_{j \tau} X_{j \tau}^{d}+M_{\tau}=Y_{\tau}+M_{\tau-1} \\
& \sum_{j=1}^{N} p_{j \tau} X_{j \tau}^{d}=M_{\tau-1}
\end{aligned}
$$

The value of the budget constraint multiplier is derived by combining equations (A4.a) and (A4.b), and substituting into equation (A4.d):

$$
\lambda_{\tau-1}=\frac{\delta^{v-\tau}}{M_{\tau-1}}
$$

Substituting the multiplier back into the combination of equations (A4.a) and (A4.b), the demand for good $j$ at period $\tau$ is:

$$
X_{j \tau}^{d}=\frac{M_{\tau-1}}{N p_{j \tau}} .
$$

Equations (A4.c) and (A4.d) imply that the amount of money carried to the next period is equal to income, which can be written as:

$$
M_{\tau}=p_{t \tau} y_{\tau}
$$

where $p_{t \tau}$ is the price index and $y_{\tau}$ is real income at period $\tau$.

Therefore, the velocity of money is constant and equals one:

$$
\frac{M_{\tau}-M_{\tau-1}}{M_{\tau-1}}=\frac{p_{t \tau}-p_{t(\tau-1)}}{p_{t(\tau-1)}}=\pi_{\tau}
$$

where $\pi_{\tau}$ is the inflation rate at period $\tau$. 


\section{Appendix B.}

\begin{tabular}{|c|c|c|c|}
\hline $\begin{array}{l}\text { Less Indebted } \\
\text { Countries }\end{array}$ & $\begin{array}{l}\text { Moderately Indebted } \\
\text { Countries }\end{array}$ & $\begin{array}{l}\text { Severely Indebted } \\
\text { Countries }\end{array}$ & $\begin{array}{l}\text { All Other } \\
\text { Countries }\end{array}$ \\
\hline Bahrain & Benin & Algeria & Australia \\
\hline Barbados & Cameroon & Argentina & Austria \\
\hline Botswana & Central Afr. Rep.* & Bolivia & Belgium \\
\hline Burkina Faso & Chile & Brazil & Burma* \\
\hline El Salvador & Colombia & Burundi* & Canada \\
\hline Fiji & Costa Rica & Congo & Cyprus \\
\hline Grenada** & Dominican Republic & Ecuador & Denmark \\
\hline Iran & Gabon & Egypt & Finland \\
\hline Korea & Gambia* & Ethiopia & France \\
\hline Lesotho & Greece & Ghana & Germany \\
\hline Malaysia & Guatemala & Guyana & Hong Kong \\
\hline Malta & Haiti & Honduras & Iceland \\
\hline Mauritius & Hungary** & Ivory Coast & Ireland \\
\hline Oman & India & Jamaica* & Israel \\
\hline Paraguay & Indonesia & Jordan & Italy \\
\hline Portugal & Malawi & Kenya & Japan \\
\hline Solomon Islands** & Nepal & Liberia & Kuwait \\
\hline South Africa* & Pakistan & Madagascar & Luxembourg \\
\hline Surinam & Papua New Guinea & Mauritania & Netherlands \\
\hline Swaziland & Philippines & Mexico & New Zealand \\
\hline Thailand & Rwanda & Morocco & Norway \\
\hline Trinidad\&Tobago & Senegal & Myanmar** & Singapore \\
\hline \multirow[t]{13}{*}{ Zimbabwe } & Sri Lanka & Nicaragua & Spain \\
\hline & Togo & Niger & Sweden \\
\hline & Tunisia & Nigeria & Switzerland \\
\hline & Turkey & Panama & Taiwan \\
\hline & Uruguay & Peru & United Arab Emirates \\
\hline & Venezuela & Sierra Leone & United Kingdom \\
\hline & & Somalia* & United States \\
\hline & & Sudan* & \\
\hline & & Syrian Arab Rep. & \\
\hline & & Tanzania & \\
\hline & & Uganda* & \\
\hline & & Zaire & \\
\hline & & Zambia & \\
\hline
\end{tabular}

${ }^{*}$ Countries included only in the regression of table 1 , but not the others. ${ }^{* *}$ Countries not included in the regressions of table 1 , but included in all others. 